\title{
IMPLEMENTASI POLA PELAYANAN YESUS SEBAGAI PELAYAN MENURUT INJIL MATIUS 4:23
}

\author{
Marthen Mau \\ Sekolah Tinggi Teologi Injili Arastamar SETIA Ngabang \\ marthenluthermau@gmail.com
}

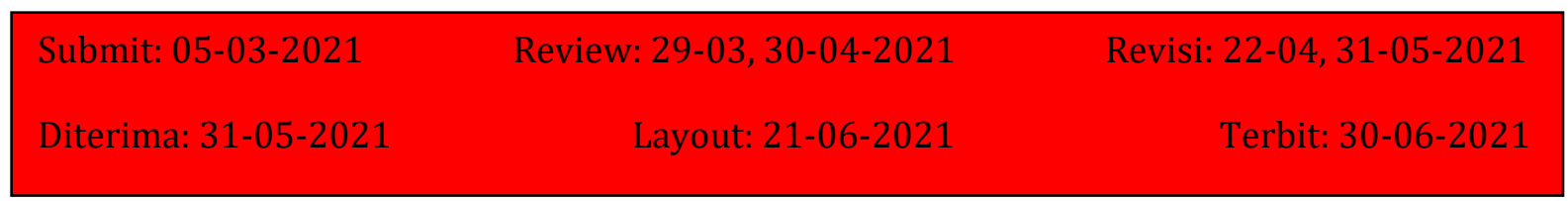

\section{Abstract}

The implementation of the pattern of Jesus' ministry in Galilee was teaching, preaching the Good News of the Kingdom of God, healing everyone who was sick, and physically weak. Jesus' ministry in Galilee was intended so that long-lost humans could hear His teaching and the proclaimed Good News, so that they could believe, accept Jesus, be healed of every disease, and physical weakness they had suffered for a long time. This study uses a qualitative method with an exegesis approach. The findings are that Christian religious education teachers must teach the teachings of Jesus, proclaim the Good News of the Kingdom of God, serve everyone who is suffering from illness, and physical/physical weakness. Through the study of exegesis, Christian religious education teachers can implement it intensely and continuously to His followers, both in church, school, and in the community.

Keywords: Implementation; the pattern of Jesus' ministry; Christian religious education teacher

\begin{abstract}
Abstrak
Implementasi pola pelayanan Yesus di Galilea ialah mengajar, memberitakan Kabar Baik Kerajaan Allah, menyembuhkan setiap orang yang menderita sakit penyakit, dan kelemahan fisik/tubuh. Pelayanan Yesus di Galilea bertujuan agar manusia yang telah lama terhilang dapat mendengarkan pengajaran-Nya dan Kabar Baik yang diproklamirkan, sehingga mereka dapat percaya, menerima Yesus, disembuhkan dari setiap penyakit, dan kelemahan fisik yang telah lama mereka derita. Penelitian ini menggunakan metode kualitatif dengan pendekatan eksegesis. Hasil temuannya bahwa para guru pendidikan agama Kristen harus mengajarkan pengajaran Yesus, memberitakan Kabar Baik Kerajaan Allah, melayani setiap orang yang menderita sakit penyakit, dan kelemahan fisik/tubuh. Melalui kajian eksegesis para guru pendidikan agama Kristen dapat mengimplementasikan secara intens dan terus-menerus kepada para pengikut-Nya, baik di gereja, sekolah, maupun lingkungan masyarakat.
\end{abstract}

Kata Kunci: Implementasi; pola pelayanan Yesus; guru pendidikan agama Kristen 


\section{Pendahuluan}

Yesus mengimplementasikan pola pelayanan sesuai rencana Allah karena Dia sebagai inisiator utama atas penyelenggaraan pelayanan di dunia. Komentar terhadap pelayanan memiliki ruang lingkup yang sangat luas. Dalam bahasa Yunani kata 'pelayanan' terdapat beberapa istilah yakni: (1) $\delta o v \lambda o \varsigma$ dapat diartikan sebagai pelayan (Mat. 10:24). Seorang pelayan perlu memiliki loyalitas dan tanggung jawab pada sang tuannya. Dia perlu mengerjakan semua hal yang menjadi kewajibannya atas perintah tuannya walaupun tidak diberikan apresiasi atau pujian dari sang majikannya; (2)

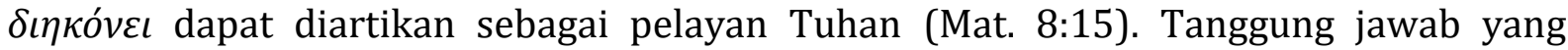
dikerjakan oleh seorang pelayan bukanlah pekerjaan yang membahagiakan tetapi pekerjaan yang membutuhkan kesabaran, ketenangan, dan penuh keuletan untuk menyelesaikannya. ${ }^{1}$

Pelayanan dalam kehidupan kristiani merupakan pelayanan kepada Yesus Kristus, yang sifatnya membangun iman orang lain melalui persekutuan dengan Tuhan. ${ }^{2}$ Oleh sebab itu, pelayanan perlu dilaksanakan oleh para pelayan Kristus Yesus termasuk guru pendidikan agama Kristen, “... layanilah seorang akan yang lain oleh kasih” (Gal. 5:13). Dalam Kitab Injil khususnya Injil Matius Yesus berperan sebagai pelayan selama masih hidup di dunia.

Sasaran pertama pelayanan Yesus dimulai dari kota Galilea. Menurut Drewes: Galilea merupakan daerah Yahudi, tetapi tidak dipedulikan oleh para rabi, ahli Taurat, dan orang Farisi karena Galilea dekat dengan wilayah bangsa-bangsa lain. Wilayah Galilea termasuk Kapernaum sangat terbuka bagi bangsa-bangsa lain. Setelah Yesus Kristus bangkit mengalahkan maut, maka sangat terbuka jalan keselamatan bagi bangsabangsa untuk percaya kepada-Nya. Karena itu Injil Kristus harus diberitakan kepada semua orang tanpa membeda-bedakan suku bangsa (Mat. 28:18-20). ${ }^{3}$

Di dalam Firman Tuhan telah dinarasikan bahwa Allah sangat mengasihi umat manusia yang berdosa untuk diselamatkan, sehingga Ia telah merelakan diri-Nya melalui karya keselamatan yang dikerjakan oleh Yesus Kristus (bdk. Yoh. 3:16). ${ }^{4}$ Menurut J. Sidlow Baxter, Yesus memilih Galilea sebagai tempat pelayanan-Nya, oleh karena Yohanes Pembaptis sebagai perintis pelayanan Tuhan Yesus telah dibungkamkan suaranya dan menandai bahwa telah tiba saatnya bagi Yesus Kristus untuk mengumandangkan suara-Nya secara nyata di hadapan umum. Tetapi di Yerusalem timbul permusuhan yang mengancam, sehingga memungkinkan dapat menggagalkan amanat dan pelayanan-Nya yang telah direncanakan sejak semula. Tanda telah diberikan, maka pilihan adalah dengan sengaja, "Menyingkirlah Ia ke Galilea."5

Penyelenggaraan pola pelayanan Yesus ke Galilea menjadi suatu kebanggaan besar bagi orang-orang Galilea. Kehadiran Yesus di tengah-tengah mereka dapat diterima dengan baik, sehingga pada setiap kesemapatan Yesus Kristus dalam berbagai kesempatan dapat mengadakan tanda-tanda ajaib dan pengajaran-Nya yang berkuasa

1 Ezra Tari, Penerapan Pola Pelayanan Yesus (Kupang: STAKN Kupang), 5; disediakan di https://www.google.com/url diakses pada tanggal 26 Mei 2021.

2 Emanuel Gerrit Singgih, Reformasi dan Transformasi Pelayanan Gereja Menyongsong Abad 21 (Yogyakarta: Kanisius, 1997), 16.

${ }^{3}$ B.E. Drewes, Satu Injil Tiga Pekabar (Jakarta: BPK Gunung Mulia, 2001), 248-249.

4 Yonatan Alex Arifianto, Reni Triposa, Paulus Karaeng Lembongan, "Studi Alkitab tentang Misi dan Pemuridan dalam Amanat Agung dan Implikasinya Bagi Kehidupan Kristen Masa Kini,"DIEGESIS: Jurnal Teologi 5 no. 2 (2020): 26.

5 J. Sdilow Baxter, Menggali Isi Alkitab 3 Matius - Kisah Para Rasul (Jakarta: YKBK/OMF, 2003), 100. 
menunjukkan diri-Nya sebagai Mesias, Anak Allah (Mat. 16:16; 26:63; Yoh. 11:27; 20:31) yang Mahatinggi.

Penulis berpendapat bahwa Yesus mengimplementasikan pola pelayanan di wilayah Galilea dilatarbelakangi oleh beberapa permasalahan, yakni: (1) Para rabi Yahudi pada waktu itu tidak mengarahkan pelayanan ke wilayah Galilea karena bagi para rabi; Galilea bukanlah wilayah pelayanan mereka; (2) para rabi Yahudi pada waktu itu hanya memfokuskan dirinya dalam pelayanan di wilayah Yerusalem dan Yudea karena bagi para rabi: Yerusalem adalah satu-satunya pusat pelayanan rohani, politik, dan keamanannya terjamin untuk pelaksanaan pelayanan dimaksud; (3) para kepala imam, para ahli Taurat, dan para rabi telah menganggap bahwa penduduk wilayah Galilea merupakan golongan bangsa-bangsa lain yang tidak layak disebut sebagai umat Allah, sehingga tidak perlu dilayani; (4) orang-orang Galilea merupakan bangsa-bangsa lain yang terkucilkan, terabaikan, tersingkirkan, atau termarjinalkan.

Menurut Adi Putra, Yesus menggunakan waktu yang banyak untuk pelayanan di Galilea memiliki alasan konkret yakni: penduduk wilayah Galilea dapat digolongkan sebagai orang-orang yang terhilang, karena itu berita pertobatan harus disampaikan seperti ungkapan Yesus bahwa, "Bertobatlah, sebab Kerajaan Surga sudah dekat!" (Mat. $4: 17^{\mathrm{b}}$ ). Kehadiran Yesus di wilayah Galilea untuk membawa mereka kembali kepadaNya. ${ }^{6}$

Implementasi pola pelayanan Yesus di Galilea menjadi masuk akal ketika Ia memberikan waktu-Nya untuk pelayanan yang bertujuan memberitakan shalom kepada penduduk wilayah Galilea sebab masyarakat Galilea dapat dianggap sebagai umat Allah yang terhilang. ${ }^{7}$ Untuk itu Kitab Injil Matius 4:23 menggoreskan beberapa pola pelayanan Yesus di Galilea, yakni mengajarkan pengajaran di tempat sembahyang, memberitakan Injil Kerajaan Allah (ay. 23), melayani para penderita sakit penyakit (ay. 23), melayani setiap orang yang menderita kelemahan fisik/tubuh (ay. 23).

Pelayanan Allah dimandatkan kepada Yesus Kristus sebagai rencana Allah yang merupakan isi hati-Nya sejak kekal dengan tujuan untuk membawa salom bagi manusia dan segenap ciptaan-Nya. ${ }^{8}$ Yesus melayani berperan sebagai pelayan Allah (bdk. Yes. 49:3; Mat. 10:24; Yoh. 13:16; 15:20); Dia telah menunjukkan loyalitas dalam menunaikan pelayanan di bumi. Pelayanan Yesus di Galilea sebagai gambaran di bumi bertujuan untuk melepaskan, membebaskan, memerdekakan, dan menyelamatkan umat manusia dari belenggu dosa (bdk. Mat. 1:21; bdk. Yes. 61:1-2).

Berhubungan dengan pola pelayanan Yesus, para guru pendidikan agama Kristen perlu melaksanakan pelayanan dalam berbagai lini kehidupan, baik di bidang kerohanian, pendidikan maupun pengajaran; bahkan tanpa membeda-bedakan latar belakang kehidupan, jenis kelamin, agama, golongan, dan suku bangsa saat mengimplementasikan pelayanannya. Guru yang baik dan alkitabiah adalah guru yang terlebih dahulu mengajar dirinya sendiri. Karena guru bukan hanya pintar dalam mengajar dan berkhotbah, tetapi mementingkan juga isi yang diajarkan dan dikhotbahkan. ${ }^{9}$

${ }^{6}$ Adi Putra, Misi Yesus Kepada Bangsa-bangsa Lain Kajian Biblika Pelayanan Yesus Berdasarkan Matius 4:12-17 (Jakarta: PT Views, 2015), 5-6.

${ }^{7}$ Adi Putra, Skripsi disediakan di https://www.google.com/search dan diakses pada tanggal 20 Mei 2021.

8 David J. Bosch, Transformasi Misi Kristen (Jakarta: BPK Gunung Mulia, 2005), 15.

${ }^{9}$ Billy Kristanto, Refleksi Atas Surat 1 Korintus: Ajarlah Kami Bertumbuh (Surabaya: Momentum, 2011), 204. 
Disadari atau tidak pada masa kini sebagian guru pendidikan agama Kristen lebih memilih pekerjaan lain dari pada mengajar dan memberitakan Kabar Baik Kerajaan Allah, baik guru pendidikan agama Kristen yang tinggal di desa maupun di kota. Pengajaran dan pemberitaan kebenaran Tuhan sangat penting untuk diajarkan dan diberitakan secara intens dan berkelanjutan dengan penuh tanggung jawab.

Dari paparan permasalahan di atas dapat dipahami bahwa penelitian ini bertujuan untuk menjawab teks Matius 4:23 yaitu: apa implementasi pola pelayanan Yesus sebagai pelayan menurut Injil Matius 4:23? Tujuan penelitian ini ialah untuk menarasikan implementasi pola pelayanan Yesus sebagai pelayan menurut Injil Matius 4:23. Hasil temuannya dapat diimplementasikan oleh para guru pendidikan agama Kristen masa kini, baik yang melayani di gereja, di lembaga pendidikan formal maupun di lingkungan masyarakat.

\section{Metode Penelitian}

Menggunakan metode penelitian kualitatif dengan pendekatan eksegesis. Metode penelitian kualitatif ialah berupaya untuk mendapatkan informasi mengenai teks yang diteliti berdasarkan pertolongan Roh Kudus. Tujuan metode penelitian kualitatif ialah untuk menemukan, mendeskripsikan, menginterpretasikan, menafsirkan, dan menarasikan sebuah teks secara ilmiah. Istilah eksegesis menggunakan kata Yuanani "exegesis" yang artinya memimpin atau membawa ke luar sebagai suatu penjelasan eksposisi dan interpretasi Alkitab. ${ }^{10}$ Pernyataan ini dapat dijelaskan bahwa eksegesis berarti mengeluarkan makna yang tepat dari kata-kata, kalimat, paragraf, atau keseluruhan kitab dengan memimpin ke luar pemahaman yang sebenarnya suatu teks yang dikaji.

Tujuan eksegesis merupakan mencari tahu konten dan maksud author dalam sebuah teks dengan memerhatikan corak gaya bahasa yang digunakannya. Jadi studi eksegesis adalah menangkap inti pesan yang disampaikan melalui teks yang dipelajari lalu upaya untuk menjelaskan, membahas, mendeskripsikan, menafsirkan, atau menarasikan secara benar sesuai dengan teks aslinya. Penulis melakukan proses analisis melalui Alkitab sebagai sumber utama dan berbagai literatur yang terpercaya untuk menghasilkan kajian yang dapat dipertanggungjawabkan.

\section{Pembahasan}

Kata "berkeliling," dari kata asli $\pi \varepsilon \rho \iota-\eta \gamma \varepsilon v$, menggunakan verb indicative imperfect active 3 singular ${ }^{11}$ yang artinya orang ketiga tunggal yang berkeliling secara aktif atau terus-menerus tanpa berhenti. Orang ketiga tunggal menurut teks ini ialah Yesus Kristus. Menurut Sutanto bahwa Dia (Yesus) berjalan keliling. ${ }^{12}$ Kata $\pi \varepsilon \rho \iota-\eta \gamma \varepsilon v$ dari kata kerja $\pi \varepsilon \rho i ́ \alpha \gamma \omega$ yang artinya untuk memimpin, melanjutkan dalam perusahaan (1Kor. 9:5), untuk melintasi (Mat. 4:23; 9:35; 23:15; Mrk. 6:6), untuk naik dan turun (Kis.

10 Nataliyana Gigih Pramono, Kumpulan Materi dan Info Belajar disediakan di https://www.google.com/ search diakses pada tanggal 4 Juni 2021.

${ }^{11}$ Scripture4all Foundation - www.scripture4all.org, 2010.

12 Hasan Sutanto, Perjanjian Baru Interlinear dan Konkordansi Jilid 1 (Jakarta: LAI, 2014), 15. 
13:11). ${ }^{13}$ Pernyataan ini dimaksudkan bahwa pada saat itu Yesus melintasi wilayah Galilea dari desa ke desa sambil mengajarkan pengajaran-Nya kepada rakyat secara umum.

Menurut B.F. Drewes dkk menyatakan bahwa $\pi \varepsilon \rho \iota-\alpha \gamma \omega$, yang artinya berkeliling14 atau saya berkeliling. Barclay M. Newman Jr bahwa $\pi \varepsilon \rho \iota-\eta \gamma \varepsilon v$, yang berarti berkeliling, berjalan keliling, menjelajah (bdk. Mat. 23:15).15 Frasa "di seluruh Galilea" (ay. 23), dari kata asli $o ́ \lambda \eta \tau \eta^{\prime} \Gamma \alpha \lambda \iota \lambda \alpha i ́ \alpha$, yang artinya di seluruh Galilea. Kata ó $\lambda \eta$ dalam teks ini dari kata ó artinya semua, keseluruhan, total. ${ }^{16}$ Jadi, Yesus melaksanakan pelayanan kepada semua orang di seluruh wilayah, baik di desa dan di kota yang terletak di Galilea (bdk. Mat. 9:35).

Pada masa lalu Yesus telah berkeliling atau mengunjungi terus-menerus di seluruh tempat yang terletak di wilayah Galilea. Kata berkeliling ini menggunakan jenis kata kerja indicative imperfect active, maka narasi mengenai Yesus terus-menerus berkeliling atau telah pergi di seluruh tempat yang terletak di wilayah Galilea adalah sebuah narasi yang benar-benar terjadi pada masa itu.

\section{A. Yesus mengajar}

Istilah mengajar (Yun. $\delta \mathrm{i} \delta \alpha \sigma \kappa \omega)$ dalam ayat 23 muncul dalam bentuk present tense. Istilah $\delta \iota \delta \alpha \sigma \kappa \omega$ berarti untuk mengajar (Mat. 4:23; 22:16-46), untuk mengajar atau berbicara di pertemuan umum (1 Tim. 2:12), untuk mengarahkan, menegur (Mat. 28:15; Rm. 2: 21- 29). ${ }^{17}$ Pernyataan di atas dapat dijelaskan bahwa istilah $\delta \iota \delta \alpha \sigma \kappa \omega$ bukan hanya sekadar untuk mengajar seseorang atau sekelompok orang tertentu melainkan berbicara di depan publik untuk mengarahkan dan menegur orang-orang yang melakukan dosa agar orang lain pun takut (bdk. 1Tim. 5:20).

Ungkapan $\delta \iota \delta \alpha \sigma \kappa \omega$ dalam ayat ini menjelaskan bahwa Yesus sedang mengajar atau Yesus terus-menerus mengajar pada saat itu. Selama Yesus melaksanakan pelayananNya di bumi, dalam kaitan dengan $\delta \iota \delta \alpha \sigma \kappa \omega$ inti pokok pengajaran Yesus ialah: (1) Yesus memberikan pengajaran-Nya mengenai etika (Mat. 5-7; Luk. 6:17-49; 11:37, dst.); (2) Yesus mengajarkan mengenai metafisika atau teologi (Mat. 11:25-27; Luk. 10:21-22; Yoh. 6:33-48; 8:58, dst.); (3) Yesus mengajarkan mengenai sosial/interaksi (Luk. 14:714; 20:19-25; Mat. 19:3-12 dst.); (4) Yesus mengajarkan mengenai keselamatan/soteriologi (Mat. 9:12-13; 11:28-30; 16:24-26; 20:28; Luk. 9:23-24; 14:1524; 15:1-32; 18:9-14; 19:9-10; Yoh. 10:1-8 dst.); (5) Yesus mengajarkan mengenai akhir zaman/eskatologi (Mat. 24:25; Mrk. 13; Luk. 21; Yoh. 14:1-3 dst.). ${ }^{18}$

Pandangan Diaz yang dikutip oleh Patrecia Hutagalung bahwa kata didasko dapat disebutkan sebanyak 97 kali dalam PB. Istilah didasko berkaitan erat dengan aktivitas pelayanan Tuhan Yesus. Saat mengajar atau mengajarkan tidak bisa pemisahan dengan penginjilan karena baik mengajar maupun penginjilan merupakan perintah Yesus

13 Samuel Bagster and Sons, The Analytical Greek Lexicon (London: Samuel Bagster and Sons, 1970),

${ }^{14}$ B.F. Drewes dkk, Kunci Bahasa Yunani Perjanjian Baru (Jakarta: BPK Gunung Mulia, 2013), 8.

15 Barclay M. Newman Jr, Kamus Yunani-Indonesia (Jakarta: BPK Gunung Mulia, 2004), 130.

16 Kalis Stevanus, Mengimplementasikan Pelayanan Yesus Dalam Konteks Misi Masa Kini Menurut Injil Sinoptik, JURNAL FIDEI 1 no. 2 (2018): 288.

${ }_{17}$ Bagster and Sons, 98.

18 Putra, Misi Yesus kepada Bangsa-Bangsa Lain, 64-65. 
Kristus yang perlu dilakukan para rasul dan gereja Tuhan selama sepanjang hayat. Jadi mengajar dan memberitakan Injil atau penginjilan perlu secara intens dan berkelanjutan. ${ }^{19}$

Pernyataan $\delta \iota \delta \alpha \sigma \kappa \omega$ dapat dijelaskan bahwa untuk membicarakan pengajaran yang benar kepada setiap orang untuk diimplementasikan (Mat. 28:15) dan untuk memberikan instruksi dalam suasana formal dan informal (Mat. 4:23; Mrk. 1:21; Yoh. 7:14; 1 Kor. 4:17; 1Tim. 4:11; 6:2). Jadi $\delta ı \delta \alpha \sigma \kappa \omega$ dapat dimengerti untuk mengajar (Mat. $4: 23 ; 22: 16)$, mengajar atau berbicara di dalam pertemuan atau di depan publik (1 Tim. 2:12), dan mengarahkan atau menegur (Mat. 28:15; Rm. 2:21) dengan kasih yang tulus.

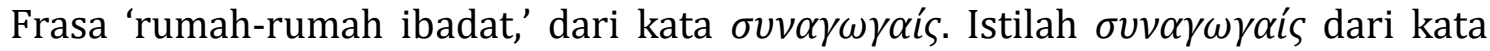

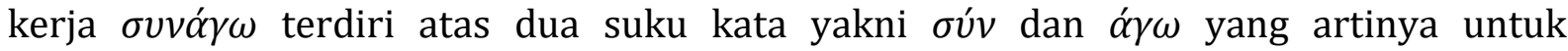
mengumpulkan bersama, mengumpulkan (bdk. Mat. 3:12; 6:26; 13:30, 47), dan untuk mengumpulkan suatu masyarakat. ${ }^{20}$ Rumah-rumah ibadat dipergunakan untuk tempat berkumpul bersama-sama sejumlah masyarakat untuk beribadah kepada Tuhan.

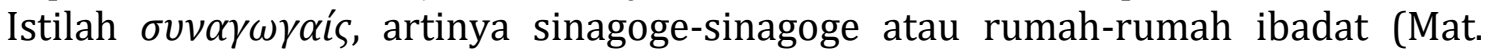
4:23), kata benda dative plural Rumah-rumah ibadat menggunakan jenis kelamin perempuan yang diibaratkan tempat yang aman untuk digunakam dalam kegiatan persekutuan. Saat Yesus Kristus melaksanakan pola pelayanan-Nya dari kota ke desa atau sebaliknya, Dia mengetahui cara menghadapi semua orang dengan metode yang berbeda-beda. Yesus mengimplementasikan metode berdasarkan lingkungan masyarakat sebagai contoh perempuan yang kedapatan berzina Kristus Yesus menyatakan pengampunan kepadanya (Mat. 19:13-15).

Menurut J. J. de Heer, pelayanan Yesus mengajar dan menyembuhkan, baik tubuh maupun jiwa supaya sama-sama diperhatikan untuk pemulihannya. Yesus mengajarkan perkataan yang benar harus diperbuat oleh manusia ${ }^{21}$ dan Yesus menyembuhkan tubuh dan jiwa manusia supaya sehat untuk memuliakan nama-Nya. Yesus mengelilingi seluruh daerah yang terletak di wilayah Galilea dalam mengajarkan mengenai Kabar Baik di sinagoge-sinagoge yang ada di wilayah Galilea tersebut. Yesus memilih sinagoge mereka sebagai objek untuk mengajarkan Kabar Baik karena tempatnya aman untuk melaksanakan aktivitas proses pengajaran. Pengajaran yang diproklamirkan oleh Yesus Kristus kepada para rasul-Nya dan para pengikut pada umumnya dengan penuh kuasa dan berwibawa untuk keselamatkan jiwa manusia.

\section{B. Yesus Memberitakan Injil}

Kata 'memberitakan' dari kata asli $\kappa \eta \rho v \sigma \sigma \omega$ yang artinya untuk mempublikasikan, memproklamasikan sebagai pembawa berita (1Kor. 9:27), untuk mengumumkan secara terbuka dan dipublikasi (Mrk. 1: 4; Luk. 4:18), menyebarkan berita kemana-mana (Mrk. $1: 45 ; 7: 36)$, untuk mengumumkan mengenai doktrin, menanamkan, memberitakan (Mat 24:14; Mrk 1:38; 13:10; Kis 15:21; Rm. 2: 21-29).22 Menurut Drewes, Haubeck, dan Von Siebenthal, Istilah $\kappa \eta \rho v \sigma \sigma \omega$ berarti memaklumkan, memberitahukan, 23 saya memproklamirkan atau saya memberitahukan. ${ }^{24}$ Sedangkan kata $\kappa \eta \rho v \sigma \sigma \omega v$ yang

19 Patrecia Hutagalung, Pemuridan Sebagai Mandat Misi Menurut Matius 28:18-20, Pengarah: Jurnal Teologi Kristen 2, no. 1, (2020): 73.

${ }^{20}$ Bagster and Sons, 385.

21 J.J. de Heer, Tafsiran Alkitab Injil Matius Pasal 1-22 (Jakarta: BPK Gunung Mulia, 2003), 63.

22 Bagster and Sons, 230.

${ }^{23}$ Drewes dkk, Kunci Bahasa Yunani Perjanjian Baru, xxxiv.

${ }^{24}$ Newman Jr, 71. 
artinya memproklamirkan. Menurut Henk ten Napel, $\kappa \eta \rho v \sigma \sigma \omega$ dalam bahasa Inggris disebut proclaim, yang artinya (1) memberitakan, menyerukan; (2) memaklumkan, memproklamasikan. ${ }^{25}$

Istilah $\kappa \eta \rho v \sigma \sigma \omega$ dapat mempublikasikan, menyatakan, sebagai seorang pemberita (bdk. 1 Kor. 9:27); untuk mengumumkan secara terbuka dan publis (bdk. Mrk. 1:4; Luk. 4:18). Menurut A. Schlatter bahwa istilah $\kappa \eta \rho v \sigma \sigma \omega$ dapat dimaknai menjadi Yesus memberitakan apa yang dilakukan oleh Tuhan. ${ }^{26}$

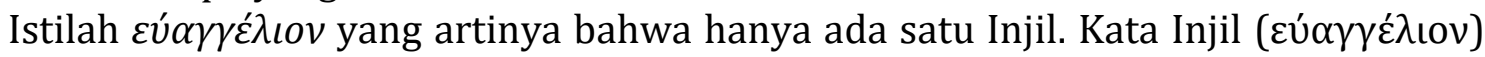
yang berarti Kabar Baik (Mat. 4:23; 24:14; Mrk. 1:14). Di dalam Alkitab kata Injil berarti berita mengenai Kerajaan Allah dan keselamatan berdasarkan iman kepada Yesus Kristus. Istilah Kerajaan Allah atau $\beta \alpha \sigma \iota \lambda$ cí $\alpha \varsigma$ dari kata $\beta \alpha \sigma \iota \lambda \varepsilon i \alpha$ yang artinya kerajaan. ${ }^{27}$ Pernyataan ini dimaksudkan bahwa Injil Kerajaan Allah harus diproklamirkan kepada orang lain agar dapat berpegang pada janji keselamatan kedatangan Tuhan Yesus Kristus sudah semakin dekat (bdk. Why. 3:11).

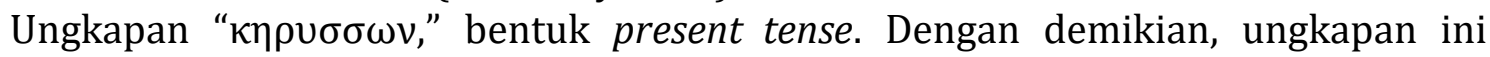
dapat dijelaskan bahwa pada saat itu Yesus terus-menerus memproklamirkan Kabar Baik Kerajaan Allah. Pelayanan pemberitaan Injil sama pemahamannya dengan pelayanan dalam pemberitaan Kerajaan Surga. Lowery dikutip oleh Patrecia Hutagalung bahwa mengumandangkan Injil Kerajaan Allah berarti melaksanakan Amanat Agung Tuhan Yesus Kristus berdasarkan Injil Matius 28:19-20.28 Pelayanan pemberitaaan Injil merupakan prioritas utama di dalam menjangkau manusia yang tidak terjangkau baik yang hidup di desa maupun di kota tanpa memandang warna kulit, gender, suku, ras, antar golongan, agama, dan kepercayaan.

Saat seseorang diundang untuk berkhotbah tidak serta merta harus seorang yang menjabat sebagai jabatan tertentu atau jabatan khusus di dalam gereja, tetapi suatu kebebasan untuk memberitakan Injil Kerajaan Allah dari siapa pun juga. J. J. de Heer menjelaskan bahwa khotbah Yesus dalam rumah-rumah ibadat (ay. 23) dimungkinkan oleh peraturan bahwa dalam rumah-rumah ibadat setiap orang laki-laki dapat diundang untuk berkhotbah, tidak perlu bahwa ia memegang suatu jabatan. ${ }^{29}$ Memberitakan Injil Kerajaan Allah yang dilakukan setiap orang yang mengasihi Yesus sudah menjadi sebuah harga mati.

Menurut F. J. Pop dalam Heer mendefinisikan Injil Kerajaan Allah merupakan kabar yang menggembirakan bahwa Tuhan akan memerintah di dunia, dan bahwa Tuhan sudah memulai mengusir semua kuasa roh jahat atau yang melawan Tuhan dan benteng-bentengnya. ${ }^{30}$ Kuasa roh jahat yang melawan Tuhan dan pekerjaan-Nya dapat disingkirkan oleh karena kuasa Roh yang ada di dalam diri orang percaya lebih besar dari kuasa roh jahat yang ada di dunia ini (bdk. 1Yoh. 4:4).

Yesus mengelilingi seluruh daerah Galilea untuk mengkhotbahkan atau memproklamirkan Kabar Baik Kerajaan Allah yang esensinya adalah kabar keselamatan yang diproklamirkan kepada para pengikut-Nya dan khalayak ramai yang berkumpul di sinagoge-sinagoge atau tempat sembahyang orang Yahudi pada masa itu.

\footnotetext{
${ }^{25}$ Henk ten Napel, Kamus Teologi Inggris-Indonesia (Jakarta: BPK Gunung Mulia, 2002), 255.

26 Heer, 63.

27 Hasan Sutanto, Perjanjian Baru Interlinear dan Konkordansi Jilid 2 (Jakarta: LAI, 2014), 136.

${ }^{28}$ Hutagalung, Pemuridan Sebagai Mandat Misi Menurut Matius 28:18-20, 66.

29 Heer, 63.

30 Ibid.
} 


\section{Yesus melenyapkan penyakit}

Kata, "melenyapkan" di dalam ayat 23 dari kata asli $\theta \varepsilon \rho \alpha \pi \varepsilon v ́ \omega$ dalam bentuk present tense, yang berarti melenyapkan secara terus-menerus. Kata 'segala penyakit,' dari kata asli $\pi \alpha ́ \alpha \alpha \nu v o ́ \sigma o v$, yang artinya setiap penyakit. ${ }^{31}$ Kata $\pi \alpha ́ \alpha \sigma \alpha$ merupakan jenis feminin, kategori jumlah singularis kasus akusatif. Di dalam ayat 23 kata $\pi \alpha ́ \sigma \alpha v$

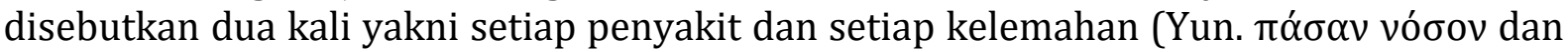

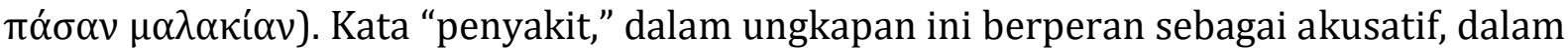

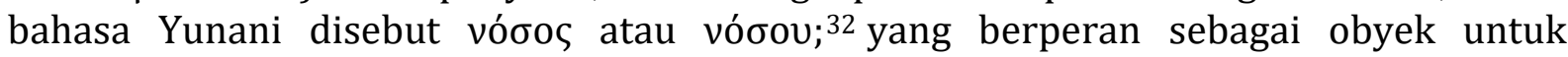
menyembuhkan ialah penyakit atau segala penyakit. Frasa 'di antara bangsa itu,' dalam frasa asli $\varepsilon^{\prime} v \tau \omega^{\prime} \lambda \alpha \omega^{\prime}$, yang berarti di antara rakyat itu. ${ }^{33}$ Lebih lanjut, Sutanto menyebutkan kata bangsa dengan istilah yang lain yakni $\lambda \alpha o ́ \varsigma$ yang berarti rakyat; umat. ${ }^{34}$

Bahwasanya berbagai penyakit yang diderita oleh orang-orang di wilayah Galilea saat itu tidak mematikan menurut perkataan Yesus Kristus sebab Yesus ialah Tabib Agung dari sorgan turun untuk melayani penyembuhan berbagai penyakit yang diderita oleh penduduk wilayah Galilea walaupun tidak mampu disembuhkan oleh tabib dari wilayah Galilea, sebab perkataan Yesus sungguh maha menyembuhkan (Yun. panpharmacon). ${ }^{35}$

Istilah untuk menyembuhkan berbagai sakit penyakit yang diderita oleh para penderita disebut $\theta \varepsilon \rho \alpha \pi \varepsilon v ́ \omega$. Istilah $\theta \varepsilon \rho \alpha \pi \varepsilon u ́ \omega$ diterjemahkan oleh LAI yakni melenyapkan penyakit. Putra mengutip ungkapan Kingsbury bahwa, "Melenyapkan penyakit merupakan bagian dari sekian banyaknya mukjizat yang dilakukan oleh Tuhan Yesus di wilayah Galilea. Dan melenyapkan penyakit tergolong ke dalam mukjizat terapeutis. Memang dalam pengisahan Injil, mukjizat-mukjizat yang dilakukan oleh Tuhan Yesus dibagi dalam dua kelompok, yakni (1) mukjizat-mukjizat yang terapeutis, dimana orang-orang sakit menjadi sehat atau orang kerasukan dibebaskan dari roh-roh jahat; (2) mukjizat-mukjizat nonterapeutis, yang berkaitan dengan kuasa atau kekuatankekuatan alam."36

Aktivitas penyembuhan yang dilakukan oleh Yesus adalah sebagai bentuk tindakan melayani. Kingsbury menyatakan bahwa penyembuhan yang dilakukan oleh Yesus sebagai bukti untuk menggenapi dalam Kitab Yesaya bahwa Dialah yang memikul kelemahan dan menanggung penyakit manusia (bdk. Mat. 8:16-17; Yes. 53:4). Pelayanan penyembuhan yang dilakukan oleh Yesus sebagai bukti bahwa Dia berperan sebagai Hamba Allah untuk melayani bangsa-bangsa lain dan umat Israel dalam memulihkan fisik yang sakit dan membebaskan mereka dari penderitaannya (bdk. Mat. 11:5). ${ }^{37}$ Berbagai macam sakit penyakit yang mampu mematikan manusia secara fisik/tubuh ternyata Yesus mampu untuk menyembuhkannya dan berbagai penyakit yang disembuhkan oleh Yesus ialah demam tinggi, sakit busung air, disentri, sakit ayan/epilepsi, dan lain sebagainya.

Yesus Kristus terus-menerus menyembuhkan setiap penyakit yang dialami oleh rakyat biasa dan suku-suku bangsa yang berdiam di seluruh daerah yang terletak di

\footnotetext{
31 Sutanto, Perjanjian Baru Interlinear dan Konkordansi Jilid 1, 15.

32 Newman Jr, 113.

${ }^{33}$ Sutanto, Perjanjian Baru Interlinear dan Konkordansi Jilid 1, 15.

34 Ibid.

35 Matthew Henry, Tafsiran Matthew Henry Injil Matius 1-14 (Surabaya: Momentum 2007), 142.

36 Putra, 54.

37 Putra, 54-55.
} 
Galilea, sebab Dia pemilik hidup semua manusia, baik yang telah percaya maupun yang tidak percaya kepada-Nya.

\section{Yesus Melenyapkan Kelemahan Fisik}

Kata "kelemahan" dari kata asli $\mu \alpha \lambda \alpha \kappa i \alpha v$, deklensi ketiga noun accusative singular feminine ${ }^{38}$ yang berarti kata benda bersifat lembut. Jadi, Yesus Kristus memberhentikan atau menyembuhkan kelemahan atau setiap kelemahan yang diderita oleh penduduk wilayah Galilea. Sutanto mengutarakan bahwa kata $\mu \alpha \lambda \alpha \kappa i \alpha v$ berarti kelemahan (karena sakit) atau $\pi \alpha ́ \alpha \sigma \alpha \mu \alpha \lambda \alpha \kappa i ́ \alpha v$ artinya setiap kelemahan (karena sakit). ${ }^{39}$ Menurut Samuel Bagster and Son kata kelemahan dari kata Yunani ialah $\mu \alpha \lambda \alpha \kappa i \alpha$ yang artinya softness, languor, in disposition, ${ }^{40}$ dapat diterjemahkan menjadi kelembutan, kelembutan, dalam watak. Istilah $\mu \alpha \lambda \alpha \kappa i \alpha$ menunjukkan kepada orang-orang yang menderita kelemahan fisik, sehingga seluruh organ tubuhnya dan dalam wataknya turut menjadi lembut.

Frasa 'kelemahan di antara bangsa itu,' dapat diterjemahkan segala macam kesakitan di antara banyak orang (AYT); cacat (BIS). Pekerjaan Yesus yang paling banyak adalah menyembuhkan atau melenyapkan setiap kelemahan tubuh yang dialami oleh manusia dan kehadiran-Nya bagi orang banyak tanpa terkecuali.

Penyembuhan yang dilakukan oleh Yesus selain sakit penyakit, juga kelemahan fisik dan segala macam kesengsaraan. Kelemahan fisik terjadi bisa sejak lahir, tetapi bisa juga karena kesalahan dalam mengatur diri secara bertanggung jawab. Kelemahan fisik yang disembuhkan oleh Yesus ialah karena disentri, batuk kering, timpang/lumpuh dan lain-lain. Penyebab terjadinya sakit penyakit, kelemahan fisik, dan segala macam sengsara bisa dipengaruhi oleh kuasa setan. Karena itu pada waktu Yesus melayani orang-orang yang mengalami kelemahan fisik dan menderita kesengsaraan; Yesus selalu mengusir roh setan yang merasuki para penderita tersebut.

\section{E. Penerapan}

\section{Mengajar Pengajaran Yesus}

Mengajar merupakan tugas penting yang harus dilaksanakan oleh para pelayan Yesus Kristus termasuk guru pendidikan agama Kristen. Mengajar adalah komponen dari esensi pelayanan yang bermanfaat bagi orang lain. Para guru pendidikan agama Kristen sebelum mengajar pengajaran Kristus yang termaktub di dalam Kitab Suci, perlu membaca Alkitab secara saksama. Francis D. Nichol dalam Stimson Hutagalung, Rolyana Ferinia bahwa Alkitab menjadi tolak ukur untuk mengajarkan mengenai keselamatan jiwa manusia. Sebab alkitablah yang menjadi sumber untuk menyatakan kesalahan, memperbaiki kelakuan, dan mendidik orang dalam kebenaran karena itu Alkitab harus dibaca atau dipelajari secara saksama. ${ }^{41}$ Tetapi Firman Tuhan tidak sekadar dibaca saja namun harus diamalkan dalam kehidupan sehari-hari termasuk mengajarkan orang lain karena Firman Tuhan berkuasa untuk mengubahkan cara hidup manusia menjadi orang yang memuliakan Nama Tuhan. ${ }^{42}$

${ }^{38}$ Interlinear Scripture Analyzer Basic.

${ }^{39}$ Sutanto, Perjanjian Baru Interlinear dan Konkordansi Jilid 1, 15.

${ }^{40}$ Bagster and Sons, 256

${ }^{41}$ Stimson Hutagalung dan Rolyana Ferinia, Menjelajahi Spiritualitas Milenial: Apakah Membaca Alkitab, Berdoa, dan Menghormati Ibadah di Gereja Menurun? JURNAL TERUNA BHAKTI 2, no 2, (2020): 102.

\footnotetext{
42 Ibid.
} 
Mengajar menurut teks Matius 4:23 berarti memberikan pengajaran kepada orang percaya supaya mereka semakin loyal kepada Kristus Yesus. Mengajar bertujuan untuk menarasikan konten dari pengajaran mengenai Kerajaan Allah. Istilah Injil berarti memproklamirkan berita keselamatan kekal di dalam Yesus Kristus kepada khalayak ramai tenpa membeda-bedakan antara satu dengan yang lainnya. Jadi Injil Kristus berarti Injil yang diproklamirkan kepada umat-Nya mengenai penjelmaan-Nya, penderitaan, kematian, dan kebangkitan yang telah mengalahkan kuasa dosa, yakni maut. Kemenangan Yesus dapat gairah atau semangat baru bagi setiap orang yang sungguh-sungguh percaya kepada-Nya.

Para guru pendidikan agama Kristen yang mengajar pengajaran Kristus tidak perlu marah-marah kepada mereka yang diajar. Menurut Stephen Tong bahwa bahwa guru yang tidak berpengaruh ialah guru yang hanya suka bermarah-marahan kepada peserta didiknya, namun peserta didik semakin dimarahi tentu akan semakin berbuat jahat. Guru yang cerdas adalah guru yang cerdas mengajarkan konten pengajaran Kitab Suci yang tepat sasaran sehingga peserta didik dapat menyadari dan meninggalkan dosanya sendiri, dan akhirnya mengaku, bertobat, menerima, dan beriman sungguh-sungguh kepada Yesus Kristus. ${ }^{43}$

Para guru pendidikan agama Kristen dalam mengajarkan pengajaran-Nya kepada warga gereja-Nya tidak perlu marah-marah, membenci, mengutuk, dan mengungkapkan pernyataan-pernyataan negatif lainnya. Pengajaran Kristus Yesus yang harus diajarkan secara bertanggung jawab supaya warga pembelajar membenci bahwa dirinya sebagai orang berdosa yang harus bertobat dan menerima Yesus Kristus secara pribadi.

Pendapat Tong bahwa mahasiswa sekolah teologi maunya hanya mengajar supaya bisa hidup mewah. ${ }^{44}$ Sebenarnya hidup mewah itu baik dan dikehendaki oleh Kristus Yesus, tetapi hidup mewah dijadikan sebagai prioritas kemudian mengabaikan pengajaran mengenai kebenaran Kristus itu yang tidak baik. Para guru pendidikan agama Kristen yang melayani di gereja seharusnya memiliki semangat juang yang tinggi dalam mengajarkan kebenaran Kristus kepada umat-Nya tanpa memikirkan kehidupan yang mewah terlebih dahulu. Mengajarkan pengajaran Yesus diharapkan supaya umatNya terus ingat akan pengajaran-Nya. Pengajaran Yesus merupakan pengajaran yang benar atau sehat, sehingga menjadi dasar pegangan di dalam hidup sehari-hari dan dengan Firman itu orang percaya dapat mengerti rencana Tuhan dan isi hati Tuhan melalui pekerjaan Roh Kudus.

\section{Berkhotbah tentang Injil Kerajaan Allah}

Injil Kerajaan Allah adalah dua hal yang memiliki kesamaan. Kesamaannya terletak pada berita yang disampaikan oleh guru pendidikan agama Kristen. Berita dimaksud adalah pribadi Yesus Kristus karena memproklamirkan Injil berarti memproklamirkan pribadi Yesus. Memberitakan Injil merupakan pelayanan untuk keselamatan orang lain yang harus dilaksanakan oleh gereja Tuhan masa kini, baik di dalam gerejanya sendiri maupun ke tempat-tempat yang belum Injil Kerajaan Allah diberitakan, ${ }^{45}$ sebab Injil Kerajaan Allah harus diproklamirkan secara terus-menerus hingga akhir hayat. 46

\footnotetext{
${ }^{43}$ Stephen Tong, Arsitek Jiwa II (Surabaya: Momentum, 2007), 23.

44 Ibid, 46.

45 Ibelala Gea, Beritakan Injil Kepada Segala Makhluk, BIA': Jurnal Teologi dan Pendidikan Kristen Kontekstual 1, no. 1 (2018): 56-57.

${ }^{46}$ Katarina \& Siswanto, Keteladanan Kepemimpinan Yesus dan Implikasinya Bagi Kepemimpinan Gereja Pada Masa Kini; Evangelikal: Jurnal Teologi Injili dan Pembinaan Warga Jemaat 2, no. 2, (2018): 92.
} 
Menurut Halim dalam Katarina dan Siswanto dalam artikelnya bahwa penginjilan dari kata Yunani euangelion yang artinya kabar baik, berita keselamatan, perdamaian, dan pengampunan bagi orang berdosa. ${ }^{47}$ Satu-satunya Pribadi yang berhak memberikan pengampunan dosa ialah Yesus Kristus. Itulah Kabar Baik yang harus diberitakan oleh orang percaya termasuk para guru pendidikan agama Kristen.

Istilah sinonim dengan memberitakan Injil Yesus Kristus ialah berkhotbah. Berkhotbah adalah suatu perkataan benar yang diberitakan oleh seorang pemberita mengenai jalan yang benar di dalam Yesus Kristus, sehingga para pendengar berita Injil tetap mempertahankan kepercayaannya kepada Tuhan Yesus Kristus. ${ }^{48}$ Kerajaan Allah merupakan inti utama pemberitaan tentang Nama Yesus Kristus. Jadi Kerajaan Allah merupakan berita baik, sebab berita ini tidak mengecewakan manusia tetapi justru menyelamatkan manusia apabila diterima dengan sepenuh hatinya tanpa ada keraguraguan. Kerajaan Allah merupakan atas inisiatif Allah untuk menghadirkannya ke bumi.

Istilah Kerajaan Allah dapat dipahami di dalam dua hal yakni: (1) pribadi Yesus Kristus yang telah datang ke dalam dunia dan berkarya bagi keselamatan umat manusia; (2) Kerajaan Allah bertalian erat dengan tempat atau wilayah yang dinantikan oleh umat yang sungguh-sungguh percaya kepada-Nya. Menurut Robi Panggarra, Kerajaan Allah merupakan pemerintahan Allah yang telah datang melalui kehadiran Yesus Kristus dan akan menjadi sempurna pada saat kedatangan-Nya untuk terakhir kalinya. ${ }^{49}$ Penekanan penting yang sangat kuat mengenai Kerajaan Allah terletak pada diri Yesus Kristus sebagai duta Allah yang melalui-Nya pemerintahan Allah itu terwujudkan.

Pemberitaan Kerajaan Allah yang telah dilaksanakan oleh Yesus Kristus, tetapi terus terwujud sampai hari ini. Kerajaan Allah adalah suatu eskatologi yang secara penuh telah terwujudkan pada masa kini. Pemenuhan waktu ini merupakan suatu periode yang berlangsung sebelum kedatangan Kerajaan Allah, suatu periode penuh pengharapan tetapi belum waktunya Kerajaan Allah itu. Jadi Kerajaan Allah telah datang selama pelayanan Yesus, namun pemenuhannya masih di depan. Karena itu, Yesus sendiri berbicara baik masa kini maupun masa depan Kerajaan itu. Kerajaan Allah yang telah datang ke dalam dunia dalam wujud Pribadi Yesus Kristus maupun akan terwujud di dalam wilayah Pemerintahan-Nya, maka seyogyanya guru pendidikan agama Kristen harus berkomitmen terus-menerus untuk memproklamirkannya di zaman ini (bdk. Mat. 28:19-20). Injil Kerajaan Allah diberitakan kepada umat manusia mulai dari Yerusalem sampai ke ujung bumi (Kis. 1:8).

Dalam pelayanan pemberitaan Injil, Tuhan Yesus ingin supaya para pengikutu-Nya tetap mengikuti aturan-Nya. William MacDonald berkata aturan dasarnya adalah bahwa para pengikut Yesus seharusnya memperlakukan orang lain sebagaimana mereka ingin diperlakukan. Hal ini berarti bahwa mereka seharusnya bersikap sopan santun, sabar, murah hati, tidak berpusat kepada diri sendiri, bersifat tidak memihak, mudah memberikan maaf, suka menolong dan masih banyak sifat yang lain. ${ }^{50}$

Berdasarkan penjelasan di atas, maka dapat disimpulkan bahwa memberitakan Injil Kerajaan Allah mengenai jalan keselamatan ialah membicarakan berita keselamatan kepada umat manusia berdasarkan Nama Yesus Kristus karena Dia satu-satunya jalan

47 Ibid.

${ }^{48}$ Dwi Setio Budiono Santoso, Peran Khotbah Gembala Sidang dalam Pertumbuhan Rohani Jemaat, MAGNUM OPUS: Jurnal Teologi dan Kepemimpinan Kristen 1, no 2 (2020): 89.

${ }^{49}$ Robi Panggarra, “Kerajaan Allah Menurut Injil-Injil Sinoptik,” Jurnal Jaffray 11 no. 1 (2013):113.

50 William MacDonald, Ikutilah Yesus! Pedoman Bagi Murid-murid Yesus (Sastra Hidup Indonesia, 2012), 27. 
menuju sorga kekal. Rothlisberger dalam Dwi Setio Budiono Santoso bahwa tujuan dari memberitakan Injil ialah supaya orang percaya mengalami pertobatan dan memeroleh keselamatan kekal. ${ }^{51}$ Para pelayan Yesus Kristus saat memberitakan Injil atau berkhotbah bukan hanya sekadar melaksanakan pelayanan secara rutinitas, melainkan bertanggung jawab secara penuh dalam mewartakan firman Tuhan sesuai dengan kehendak Allah.

\section{Melayani orang sakit}

Melayani orang-orang yang menderita sakit penyakit menjadi hal yang penting dalam kehidupan orang percaya khususnya para pelayan Tuhan, baik hamba-hamba Tuhan maupun para penatua jemaat. Oleh karena pada masa pelayanan Yesus Kristus selain mengajar dan berkhotbah tetapi Dia juga menyembuhkan orang-orang sakit. Belas kasihan Yesus terhadap para penderita sakit penyakit pada masa itu sangat tinggi. Pelayanan penyembuhan yang telah dilakukan oleh Yesus secara terus-menerus pada masa itu perlu para guru pendidikan agama Kristen melayani orang-orang yang menderita berbagai penyakit pada masa kini.

Setiap orang yang menderita bermacam-macam penyakit ketika berkeinginan untuk mengalami kesembuhan, maka perlu mengetahui langkah-langkah memeroleh penyembuhan seperti tertulis di dalam Alkitab Penuntun Hidup Berkelimpahan:

1. Setiap orang yang mengalami sakit penyakit bisa beroleh kesembuhan apabila hubungan dengan Kristus Yesus dan orang lain beres (bdk. Mat. 6:33; 1 Kor. 11:27-30; Yak. 5:16).

2. Mencari kehadiran Yesus dalam kehidupan sehari-hari karena Dialah yang mengaruniakan iman kepada setiap orang yang percaya kepada-Nya (Rm. 12:3; 1 Kor. 12:9; Flp. 2:13).

3. Kehidupan setiap orang dipenuhi dengan firman Tuhan (Yoh. 15:7; Rm. 10:17).

4. Setiap orang tetap tinggal di dalam Yesus Kristus apabila belum beroleh kesembuhan (Yoh. 15:1-7).

5. Mintalah dukungan doa dari para pelayan Tuhan termasuk para penatua jemaat (presbuteros) (Yak. 5:14-16).

6. Hadirilah kebaktian dimana ada hamba Tuhan yang memiliki karunia penyembuhan (bdk. Mat. 5:15-16; 8:5-7).

7. Percayalah kepada kuasa Kristus Yesus sebab masih ada mukjizat hingga saat ini (Mat. 7:8; 19:26).

8. Bersukacitalah di dalam Kristus Yesus, baik sudah menerima kesembuhan atau belum mengalami kesembuhan (Flp. 4:4; 11-13). ${ }^{52}$

Pelayanan kesembuhan yang dilayani oleh guru pendidikan agama Kristen terhadap orang-orang yang menderita sakit penyakit amatlah penting tetapi penyembuhannya mutlak terjadi atas kehendak Yesus Kristus. Karena itu, bagi mereka yang belum mengalami kesembuhan harus bersabar dan tetap bersukacita di dalam Kristus Yesus. Kesembuhan atas setiap penyakit menurut teks Matius 4:23 dapat diketahui bahwa mereka yang buta (Mat. 9:27-31; 15:29-31; 20:29-34; Mr. 8:22-26), bagi mereka yang tuli (Mrk. 7:31-37), bagi mereka yang bisu (Mat. 15:29-31; Mrk. 9),

\footnotetext{
${ }^{51}$ Santoso, Peran Khotbah Gembala Sidang dalam Pertumbuhan Rohani Jemaat, 89.

52 Tim Penyusun, Alkitab Penuntun Hidup Berkelimpahan (Jakarta: Gandum Mas \& LAI, 2010), 1517.
} 
bagi mereka yang lumpuh (Mat. 9:1-8; 15:29-31), bagi mereka yang timpang (Mat. 15:29-31) dan berbagai macam penyakit lainnya dapat disembuhkan oleh Yesus Kristus. Yesus Kristus menyembuhkan para penderita sakit penyakit sebagai bukti bahwa para penderita sakit penyakit telah mendengar dan percaya kepada Yesus Kristus sebagai Juruselamatnya.

Kesembuhan yang terjadi pada masa pelayanan Yesus terus berkelanjutan sampai masa kini. Karena itu, para guru pendidikan agama Kristen saat ini mendoakan orangorang sakit akan mengalami kesembuhan apabila sungguh-sungguh percaya kepada Yesus Kristus. Jadi, guru pendidikan agama Kristen hanya sebagai alat di tangan Tuhan untuk melayani orang-orang sakit tetapi penentuan untuk kesembuhan merupakan tindakan dan kedaulatan dari Kristus Yesus.

Menurut J.J. de Heer, bahwa para penderita sakit penyakit dapat dipulihkan oleh Kristus Yesus melalui doa yang muncul dari dalam hati yang tulus, suci, murni, dan sungguh-sungguh kepada-Nya, sehingga Dia bertindak melalui kehendak-Nya bukan kehendak para pendoa. ${ }^{53}$ Para pendoa hanya sebagai alat di tangan Tuhan tetapi yang mutlak untuk menyembuh para penderita sakit penyakit ialah Tuhan Yesus Kristus.

\section{Melayani orang yang lemah fisik}

Istilah "malakian," di dalam teks Matius 4:23 mengindikasikan pemahaman tentang penyakit atau kelemahan yang dapat menimpah manusia di antaranya ialah kusta (Mat. 8:4; Luk. 17), pendarahan (Mat. 9:20; Mrk. 5:27), batuk kering, dan disentri. Disentri merupakan demam lambung atau sakit perut yang hebat. Yoram, raja Yehuda, meninggal dalam penderitaan hebat karena disentri yang kronis (2 Taw. 21:18).

Ayah Publius menderita penyakit disentri, yang merupakan penyakit umum di Malta dan disembuhkan oleh Yesus melalui rasul Paulus (Kis. 28:8). Pulau Malta merupakan pulau yang penduduknya rawan mengalami penyakit disentri dan jika lambat ditangani bisa menimbulkan korban jiwa.

Jenis kelemahan khusus lain, yang juga turut dilumpuhkan, disembuhkan, dan dimatikan oleh Yesus sampai ke akar-akarnya yakni: (1) penderita kelumpuhan fisik atau tubuh (bdk. ay. 24); (2) penderita sakit ayan dalam ilmu kedokteran disebut epilepsi (ay. 24).

\section{Kesimpulan}

Satu-satunya Pemberi keselamatan kekal hingga menuju ke dalam wilayah Kerajaan Allah atau Kerajaan Sorga ialah Tuhan Yesus Kristus. Untuk itu mengajar dan memproklamirkan Kabar Baik Kerajaan Allah merupakan pola pelayanan Yesus yang harus diimplementasikan secara intens dan berkelanjutan oleh para guru pendidikan agama Kristen pada masa kini. Pelayanan untuk menyembuhkan para penderita penyakit dan para penderita fisik/tubuh bukan suatu pelayanan yang menjadi prioritas terpenting tetapi merupakan bagian dari pelayanan penyembuhan yang dilakukan oleh Yesus ketika orang-orang telah mendengar pengajaran-Nya dan menjadi percaya kepada Yesus Kristus.

\footnotetext{
53 Heer, 63.
} 
Dengan demikian, para guru pendidikan agama Kristen harus mengajar dan memberitakan Injil Kerajaan Allah secara terus-menerus kepada para pengikut Yesus agar mereka tetap percaya, menerima, dan beriman sungguh-sungguh kepada Yesus, maka hidupnya akan berubah serupa dengan Kristus. Bahkan mereka yang menderita sakit penyakit dan mengalami kelemahan fisik akan beroleh kesembuhan yang dikerjakan oleh Yesus Kristus sebagai Tabib dari Sorga melalui pelayanan para guru pendidikan agama Kristen pada masa kini.

\section{Referensi}

Scripture4all Foundation - www.scripture4all.org. 2010.

Arifianto, Yonatan Alex, Triposa, Reni, Lembongan, Paulus Karaeng, "Studi Alkitab tentang Misi dan Pemuridan dalam Amanat Agung dan Implikasinya Bagi Kehidupan Kristen Masa Kini," Jurnal Teologi Kharismatika: dIEGESIS 5 no. 2 (2020): 25-42

Bagster, Samuel and Sons. The Analytical Greek Lexicon. London: Samuel Bagster and Sons, 1970.

Baxter, J. Sdilow. Menggali Isi Alkitab 3 Matius - Kisah Para Rasul. Jakarta: YKBK/OMF, 2003.

Bosch, David J. Transformasi Misi Kristen. Jakarta: BPK Gunung Mulia, 2005.

Drewes, B.E. Satu Injil Tiga Pekabar. Jakarta: BPK Gunung Mulia, 2001.

Drewes, B.F. dkk. Kunci Bahasa Yunani Perjanjian Baru. Jakarta: BPK Gunung Mulia, 2013.

Gea, Ibelala, Beritakan Injil Kepada Segala Makhluk, BIA': Jurnal Teologi dan Pendidikan Kristen Kontekstual 1, no. 1 (2018): 56-69.

Heer, J.J. de. Tafsiran Alkitab Injil Matius Pasal 1-22. Jakarta: BPK Gunung Mulia, 2003.

Henry, Matthew. Tafsiran Matthew Henry Injil Matius 1-14. Surabaya: Momentum, 2007.

Hutagalung, Patrecia. Pemuridan Sebagai Mandat Misi Menurut Matius 28:18-20, Pengarah: Jurnal Teologi Kristen 2, no. 1, (2020): 64-76.

Hutagalung, Stimson dan Ferinia, Rolyana. Menjelajahi Spiritualitas Milenial: Apakah Membaca Alkitab, Berdoa, dan Menghormati Ibadah di Gereja Menurun? JURNAL TERUNA BHAKTI 2, no 2, (2020): 97-111.

Interlinear Scripture Analyzer Basic.

Katarina \& Siswanto. Keteladanan Kepemimpinan Yesus dan Implikasinya Bagi Kepemimpinan Gereja Pada Masa Kini. Evangelikal: Jurnal Teologi Injili dan Pembinaan Warga Jemaat 2, no. 2, (2018): 87-98.

Kristanto, Billy. Refleksi Atas Surat 1 Korintus: Ajarlah Kami Bertumbuh. Surabaya: Momentum, 2011.

MacDonald, William. Ikutilah Yesus! Pedoman Bagi Murid-murid Yesus. Sastra Hidup Indonesia, 2012.

Napel, Henk ten. Kamus Teologi Inggris-Indonesia. Jakarta: BPK Gunung Mulia, 2002.

Newman Jr, Barclay M. Kamus Yunani-Indonesia. Jakarta: BPK Gunung Mulia, 2004.

Panggarra, Robi. Kerajaan Allah Menurut Injil-Injil Sinoptik. Jurnal Jaffray 11 no. 1 (2013): 109-128.

Penyusun, Tim, Alkitab Penuntun Hidup Berkelimpahan. Jakarta: Gandum Mas \& LAI, 2010. 
Pramono, Nataliyana Gigih, Kumpulan Materi dan Info Belajar disediakan di https://www.google.com/ search diakses pada tanggal 4 Juni 2021.

Putra, Adi, Skripsi. Jakarta: SETIA Jakarta, 2014, 7. Disediakan di https://www.google.com/search dan diakses pada tanggal 20 Mei 2021.

Putra, Adi. Misi Yesus Kepada Bangsa-bangsa Lain Kajian Biblika Pelayanan Yesus Berdasarkan Matius 4:12-17. Jakarta: PT Views, 2015.

Santoso, Dwi Setio Budiono. Peran Khotbah Gembala Sidang dalam Pertumbuhan Rohani Jemaat, MAGNUM OPUS: Jurnal Teologi dan Kepemimpinan Kristen 1, no 2 (2020): 88-97.

Singgih, Emanuel Gerrit, Reformasi dan Transformasi Pelayanan Gereja Menyongsong Abad 21. Yogyakarta: Kanisius, 1997.

Stevanus, Kalis. Mengimplementasikan Pelayanan Yesus Dalam Konteks Misi Masa Kini Menurut Injil Sinoptik. JURNAL FIDEI 1 no. 2 (2018):284-298.

Sutanto, Hasan. Perjanjian Baru Interlinear dan Konkordansi Jilid 1. Jakarta: LAI, 2014. . Perjanjian Baru Interlinear dan Konkordansi Jilid 2. Jakarta: LAI, 2014.

Tari, Ezra, Penerapan Pola Pelayanan Yesus (Kupang: STAKN Kupang), 5; disediakan di https://www.google.com/url diakses pada tanggal 26 Mei 2021.

Tong, Stephen. Arsitek Jiwa II. Surabaya: Momentum, 2007. 